\title{
Description of a new sepioline species, Sepiola boletzkyi sp. nov. (Cephalopoda: Sepiolidae), from the Aegean Sea
}

\author{
Giambattista BELLO ${ }^{1, *} \&$ Alp SALMAN ${ }^{2}$ \\ ${ }^{1}$ Arion, Via Colombo 34, 70042 Mola di Bari, Italy. \\ ${ }^{2}$ Ege University, Faculty of Fisheries, Department of Hydrobiology, 35100, Bornova, Izmir, Turkey. \\ E-mail: alp.salman@ege.edu.tr \\ * Corresponding author: giamb.bello@gmail.com \\ ${ }^{1}$ urn:1sid:zoobank.org:author:31A50D6F-5126-48D1-B630-FBEDA63944D9 \\ ${ }^{2}$ urn:1sid:zoobank.org:author:76C095B6-A975-49D4-BDF0-0802B03E9B4C
}

\begin{abstract}
A new sepioline species, Sepiola boletzkyi sp. nov. (Cephalopoda: Sepiolidae), is described based on two specimens from the Aegean Sea (eastern Mediterranean). The type specimens are lodged in the Ege University Faculty of Fisheries Museum of Izmir (Turkey). The new species belongs to the Sepiola atlantica group sensu Naef, hence it is compared with the species in this group, namely Sepiola affinis, Sepiola atlantica, Sepiola bursadhaesa, Sepiola intermedia, Sepiola robusta, Sepiola rondeletii, Sepiola steenstrupiana and Sepiola tridens. The male of S. boletzkyi sp. nov. differs from all the others in having the combination of homomorphous ventral arm tips, eight enlarged suckers, subdivided into two groups, in the dorsal row of the distal part of the hectocotylus and a dorsal lobe complementing the copulatory apparatus. In females of $S$. boletzkyi sp. nov. the bursa copulatrix is large and, unlike all other species in the genus, has a large fungiform process towards the mantle wall. The discovery of $S$. boletzkyi sp. nov. increases to 12 the number of NE Atlantic-Mediterranean species of Sepiola.
\end{abstract}

Keywords. Cephalopoda, Sepiolidae, Sepiola boletzkyi sp. nov., Aegean Sea, Mediterranean Sea.

Bello G. \& Salman A. 2015. Description of a new sepioline species, Sepiola boletzkyi sp. nov. (Cephalopoda: Sepiolidae), from the Aegean Sea. European Journal of Taxonomy 144: 1-12. http://dx.doi.org/10.5852/ ejt.2015.144

\section{Introduction}

The genus Sepiola Leach, 1817 (Cephalopoda: Sepiolida: Sepiolidae) is the most speciose sepioline genus in the NE Atlantic-Mediterranean region, where it is represented by 11 species (Bello 2013). Eight of them, Sepiola affinis Naef, 1912, Sepiola atlantica d'Orbigny, 1841, Sepiola bursadhaesa Bello, 2013, Sepiola intermedia Naef, 1912, Sepiola robusta Naef, 1912, Sepiola rondeletii Leach, 1817, Sepiola steenstrupiana Levy, 1912 and Sepiola tridens de Heij \& Goud, 2010, belong to the Sepiola atlantica group sensu Naef (1923), which is characterized by the peculiar morphology of the male copulatory apparatus (Fig. 1). Sepiola atlantica and S. tridens are endemic to the Atlantic Ocean, all other species live in the Mediterranean Sea (Bello 2013). Two more species occur in the Mediterranean, namely Sepiola aurantiaca Jatta, 1896 and Sepiola ligulata Naef, 1912 (Bello 2003). 
In the paper describing S. bursadhaesa, the most recently defined Sepiola species, Bello (2013: 498) stated "Because of the [...] combination of factors that facilitates speciation [in Sepiola], it is likely that other, still undescribed species of this genus await discovery." An additional Mediterranean species, viz. Sepiola boletzkyi sp. nov., was discovered in the Aegean Sea and is described in the present paper.

\section{Material and methods}

The sepiolines were caught by a hand-operated $1 \mathrm{~mm}$ mesh size tulle net, during daytime. In the laboratory they were measured (mantle length) and fixed in 10\% formalin in seawater. Afterwards they were preserved in $70 \%$ ethyl alcohol.

The sample consists of two specimens which are housed in the Ege Üniversitesi Su Ürünleri Fakültesi Müzesi (ESFM) (Ege University Faculty of Fisheries Museum) of Izmir (sample nos. CEP/1994-1 and CEP/1994-2). Subsequent samplings, carried out in recent times in the same area, did not provide any additional specimens of this new species.

The photographs of anatomical details were taken with a digital camera (DFC 420, Leica, Cambridge, U.K.) attached to a stereo microscope.

Measurements were taken on the preserved specimens, except mantle length, which was also taken before preservation, following Roper \& Voss (1983) and Reid (2009). Indices were calculated by expressing each measure as a percentage of mantle length; their acronyms are defined in Table 1 next to each measurement designation.

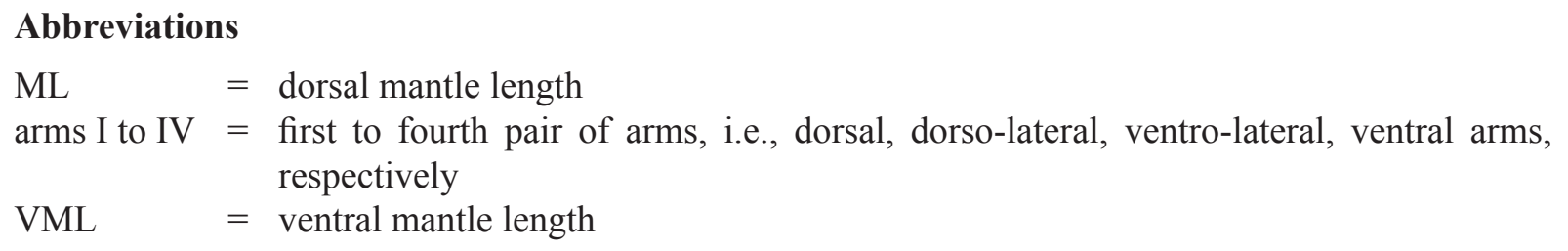

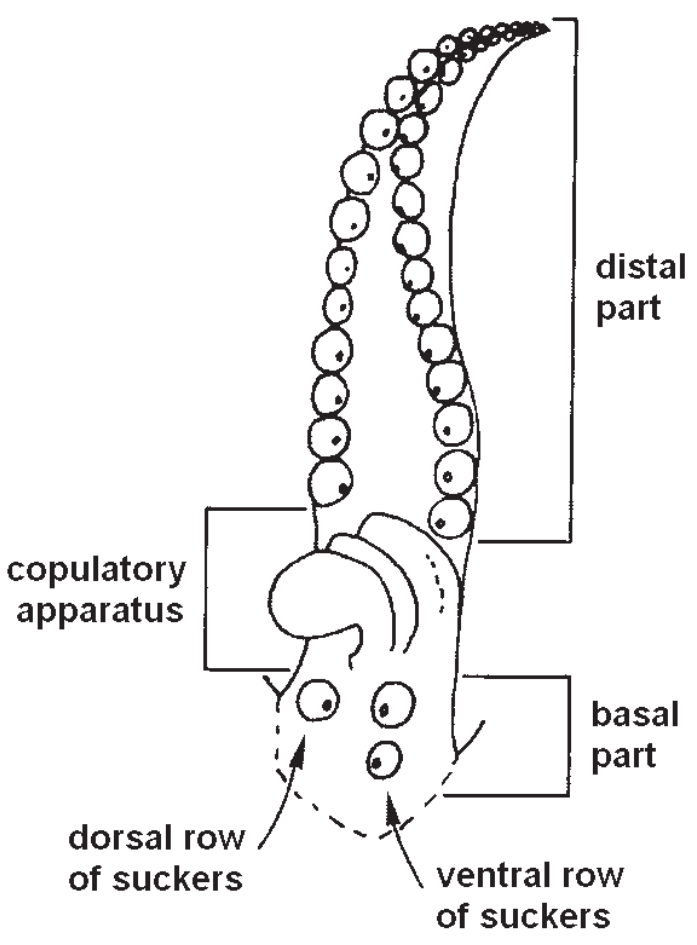

Fig. 1. Schematic rendering of the general hectocotylus (left arm I) in the Sepiola atlantica group sensu Naef (1923) (after Bello 1995, modified). 


\section{Results}

Class Cephalopoda Cuvier, 1797

Subclass Coleoidea Bather, 1888

Order Sepiolida Fioroni, 1981

Family Sepiolidae Leach, 1817

Subfamily Sepiolinae Leach, 1817

Genus Sepiola Leach, 1817

Sepiola Leach, 1817: 137. Type species Sepiola rondeletii Leach, 1817, by monotypy.

\section{Diagnosis}

Sepiolines with pair of kidney-shaped light-organ lenses on ventral surface of ink sac; suckers biserial on arms I to III and at least proximally on arms IV; tentacle club suckers in four to eight oblique rows; females with ear-shaped bursa copulatrix on left ventral side of mantle cavity; males with left arm I hectocotylized: suckers and sucker stalks typically arranged in a basal part, a copulatory apparatus comprised of modified suckerless stalks, and a distal part (Bello 2013).

Sepiola boletzkyi sp. nov. urn:1sid:zoobank.org:act:A6A9644D-61E6-4964-9460-A8037035391D

Figs 2-7, Tables $1-2$

\section{Diagnosis}

Sepiola with biserial suckers on all arms, including tips of arms IV. Tentacle clubs with six oblique rows of equal-sized suckers. Hectocotylus typical of the Sepiola atlantica group sensu Naef (1923) (Fig. 1): (1) three regular equal-sized suckers in basal part; (2) copulatory apparatus with roundish dorsal tubercle, weakly developed, complemented by broad lobe, dorsomedial to tubercle; (3) sequence of modified suckers in dorsal row of distal part: (a) two small, (b) six markedly enlarged, (c) one small and (d) two enlarged suckers; (4) no dorso-lateral groove on medial side of distal part. Bursa copulatrix moderately large and ear-shaped, anteriorly extended below the left light-organ, with a large fungiform process towards mantle wall posterior to gill insertion.

\section{Etymology}

From the family name of the eminent teuthologist Sigurd von Boletzky, in recognition of his enormous contribution to teuthology.

\section{Material examined}

Holotype

ô, ESFM-CEP/1994-1, mature, ML: 20 mm fresh, $16.8 \mathrm{~mm}$ preserved.

\section{Paratype}

O, ESFM-CEP/1994-2, immature, ML: $19 \mathrm{~mm}$ fresh, $17.2 \mathrm{~mm}$ preserved. Same locality as holotype.

\section{Type locality}

TURKEY: Gulf of Ildir, Aegean Sea, eastern Mediterranean Sea, off Sifne (Çeşme District, Izmir Province), $38^{\circ} 19^{\prime} 32^{\prime \prime} \mathrm{N} 26^{\circ} 24^{\prime} 14^{\prime \prime} \mathrm{E}$, on a sandy bottom covered by eel-grass, Zostera sp., at a depth of 2 m, Apr. 1994. 


\section{Description}

Medium size Sepiola; maximum recorded ML $=20 \mathrm{~mm}$, male (fresh specimen); maximum recorded $\mathrm{TL}$, without tentacles $=40.5 \mathrm{~mm}$, male (arms are variously curled up in both specimens). Tentacles exceed TL by $6-9 \mathrm{~mm}$ (tentacle and clubs are variously curled up in both specimens). Measurements are reported in Table 1.

Body shape corresponds to general shape of NE Atlantic-Mediterranean Sepiola species (Fig. 2). Mantle sac-shaped, broadly rounded at posterior end, length exceeds width, outline U-shaped. Dorsal mantle margin fused to head by cutaneous nuchal band $27-31 \%$ of ML. Ventral mantle margin very slightly sinuate, with very low barely visible rounded projection on each side of funnel (Fig. 2). VML approximately $89-98 \%$ of ML. Fins typical for Sepiola, each inserted midway along sides of mantle, broadly rounded; fin length slightly exceeds half ML, fin width about $70-80 \%$ of fin length, insertion line about $60 \%$ of overall fin length. Head width $65-69 \%$ of ML in both specimens. Eyes large, bulging beyond sides of the head, covered by corneal membrane and bordered by secondary eyelid. Funnel long about $60 \%$ of ML, covered posteriorly by ventral margin of mantle, funnel free length about $40 \%$ of ML; distal end does not reach junction of ventral arms.

Arm formula II = III > IV > I in both specimens. Arms slightly longer in male than in female. Suckers stalked, alternately placed in two series on oral side of all arms, including distal-most part of arms IV.

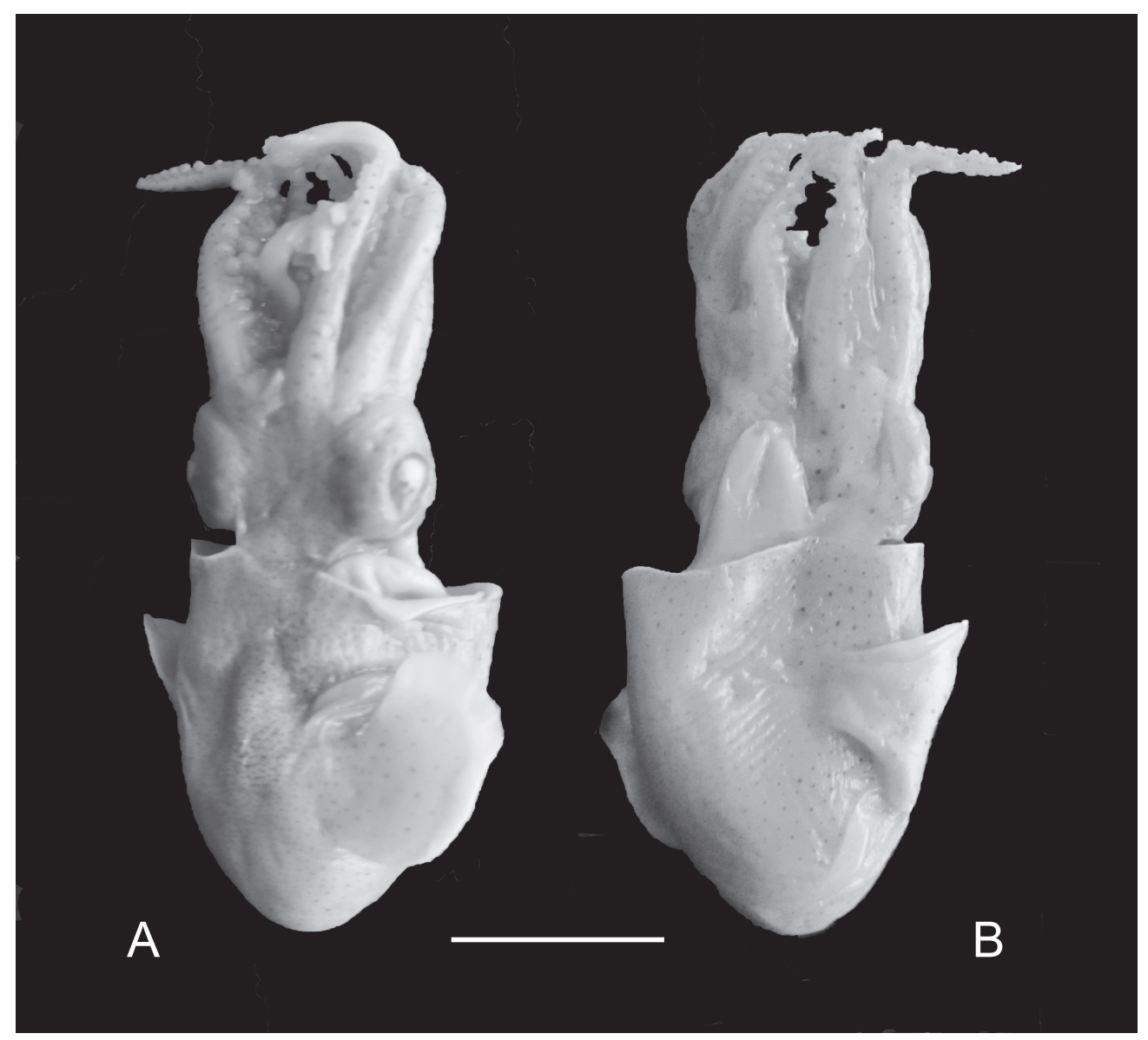

Fig. 2. Sepiola boletzkyi sp. nov., holotype, Ô, ESFM-CEP/1994-1. The hectocotylus was removed for closer examination. A. Dorsal view. B. Ventral view. Scale bar $=1 \mathrm{~cm}$. 
BELLO G. \& SALMAN A., Sepiola boletzkyi sp. nov. from the Aegean Sea

Table 1. Measurements and indices of type specimens of Sepiola boletzkyi sp. nov., MLs in square brackets are those taken on fresh specimens prior to preservation.

\begin{tabular}{|c|c|c|}
\hline & $\begin{array}{c}\text { Holotype, }{ }^{\lambda} \\
(\mathrm{mm} / \%)\end{array}$ & $\begin{array}{c}\text { Paratype, }, \\
(\mathbf{m m} / \%)\end{array}$ \\
\hline dorsal mantle length / ML & $16.8[20]$ & $17.2[19]$ \\
\hline ventral mantle length / VMLI & $16.4 / 97.6$ & $15.3 / 89.0$ \\
\hline total length & 40.5 & 38.6 \\
\hline total length, including tentacles & 46.8 & 47.2 \\
\hline arm I length, right and left (hectocotylus) / A1LI & $12.9 / 76.8-8.5 / 50.6$ & $9.3 / 54.1$ \\
\hline arm II length / A2LI & $14.9 / 88.7$ & $13.0 / 75.6$ \\
\hline arm III length / A3LI & $14.8 / 88.1$ & $13.3 / 77.3$ \\
\hline arm IV length / A4LI & $13.3 / 79.2$ & $10.7 / 62.2$ \\
\hline mantle width / MWI & $14.1 / 83.9$ & $13.5 / 78.5$ \\
\hline head width / HWI & $11.0 / 65.5$ & $11.8 / 68.6$ \\
\hline head length / HLI & $7.1 / 42.3$ & $6.9 / 40.1$ \\
\hline fin length / FLI & $9.3 / 55.4$ & $9.1 / 52.9$ \\
\hline fin width / FWI & $6.4 / 38.1$ & $7.2 / 41.9$ \\
\hline fin insertion / FII & $5.7 / 33.9$ & $5.6 / 32.6$ \\
\hline distance fin anterior insertion - mantle border / FiaI & $5.6 / 33.3$ & $5.4 / 31.4$ \\
\hline nuchal commissure width / NCI & $4.3 / 25.6$ & $5.4 / 31.4$ \\
\hline funnel length / FuLI & $10.1 / 60.1$ & $10.6 / 61.6$ \\
\hline free funnel length / FfuLI & $6.7 / 39.9$ & $7.1 / 41.3$ \\
\hline funnel locking cartilage length / FuCartLI & $4.0 / 23.8$ & $4.5 / 26.2$ \\
\hline tentacle club length / ClLI & $8.0 / 47.6$ & $8.0 / 46.5$ \\
\hline gladius length / GLI & - & $8.5 / 49.4$ \\
\hline
\end{tabular}
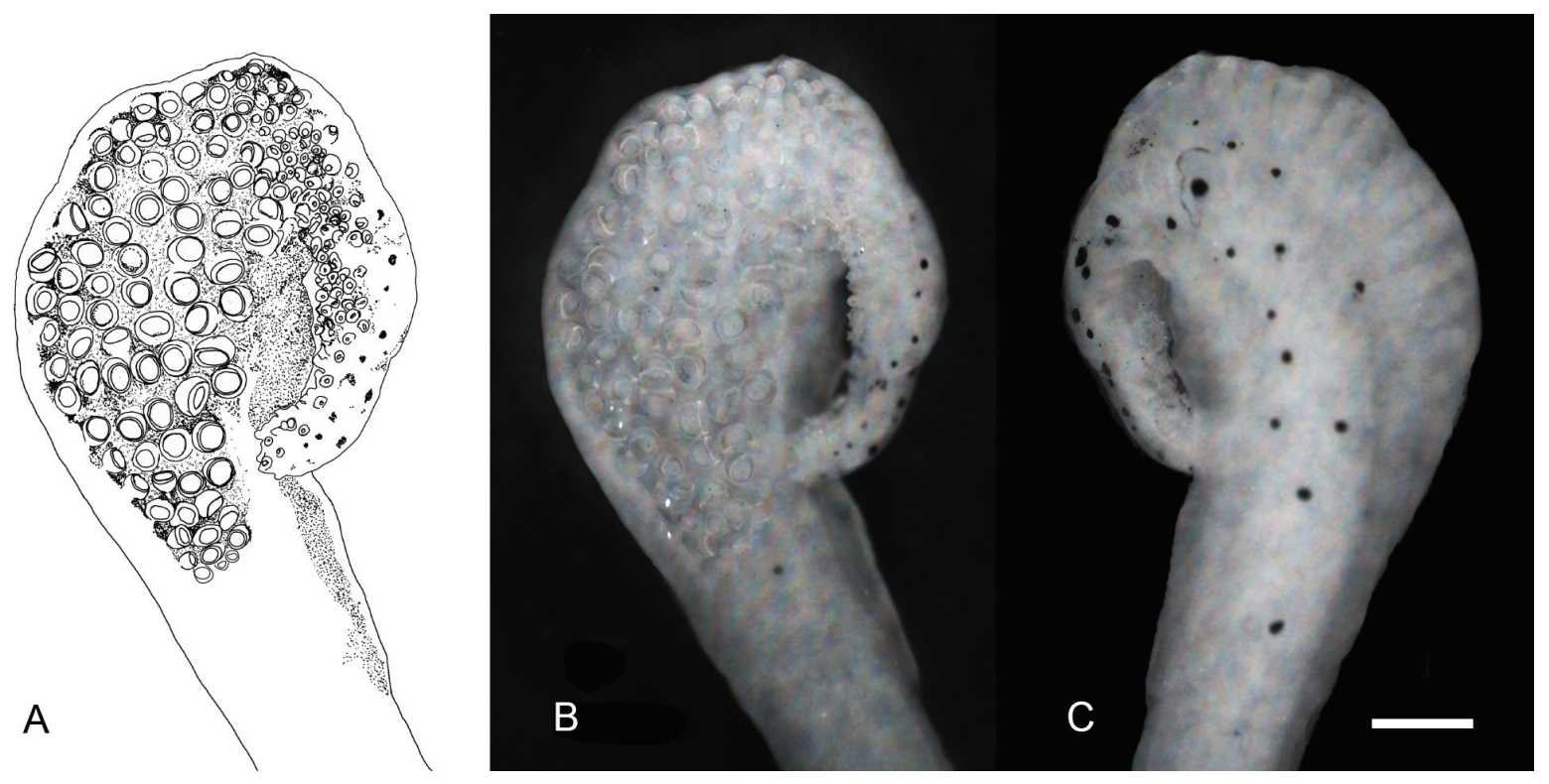

Fig. 3. Right tentacle club of Sepiola boletzkyi sp. nov., holotype, ô, ESFM-CEP/1994-1. A. Oral view (drawing). B. Oral view. C. Dorsal view. Scale bar $=1 \mathrm{~mm}$. 
Table 2. Measurements taken on beaks of the paratype, + , ESFM-CEP/1994-2, of Sepiola boletzkyi sp. nov., definitions according to Clarke (1986) and Açik \& Salman (2010).

\begin{tabular}{|cc|}
\hline Upper beak & Lengths $(\mathbf{m m})$ \\
\hline Rostrum & 0.7 \\
Hood & 2.6 \\
Total & 4.8 \\
Wing & 1.6 \\
\hline Lower beak & Lengths (mm) \\
\hline Rostrum & 0.8 \\
Hood & 1.2 \\
Wing & 1.1 \\
Crest & 2.6 \\
\hline
\end{tabular}

Brachial crown of mature males displays sexual dimorphic features (see below for detailed description). Arm web reduced; encloses base of tentacles between arms III and IV.

Tentacles thin and delicate. Tentacular club longitudinally lined by protective membranes more developed and ventrally trabeculate (width $1.5-2 \mathrm{~mm}$ ); distal third of club abruptly tapered, elongate; club suckers equal sized in six oblique rows (Fig. 3).

Overall skin colouration pale violet brown; most chromatophores not expanded. (Actual colouration undoubtedly altered by several year storage in ethyl alcohol.) No particular chromatophore distribution pattern observed.

Mantle-locking apparatus straight, as typical for the genus, long about $1 / 4 \mathrm{ML}$.

Gladius positioned sagittally on inner face of dorsal mantle, encased in shell sac (see Bizikov 2008 for general description of sepiolid gladius). Gladius reduced, extends from anterior mantle margin to about $45 \%$ of ML, posterior tip does not reach posterior end of mantle (as is typical for the genus). Gladius shape similar to those reported for S. bursadhaesa (Bello 2013) and S. aurantiaca (Jatta 1896) (Fig. 4). Chitinous rachis light tan-coloured, widely open V-shaped in cross section. Gladius bluntly pointed at anterior extremity then gradually enlarges to reach width of about $4 \%$ of GL $(0.32 \mathrm{~mm}$ in examined specimen); posteriorly, two sides of rachis run almost parallel to about $55 \%$ of GL and subsequently converge to a point short of posterior end. Point where rachis starts to narrow corresponds to anterior insertion of thin and transparent lateral plates. Posterior part of gladius spear-head shaped where rachis is the shaft and lateral plates the two lateral blades that taper posteriorly to a narrow point exceeding the convergence point of the rachis by about $2.5 \%$ of GL.

Beaks indistinguishable from those of other NE Atlantic-Mediterranean Sepiola species ( $c f$. Açik \& Salman 2010) (Fig. 5). Female beak measurements are shown in Table 2. Upper beak rostrum uniformly curved; jaw angle obtuse; wing long as anterior lateral wall margin, shoulder (cutting edge) straight, its margin neatly separated at an obtuse angle from rostrum; no grooves at hood sides; no lateral wall

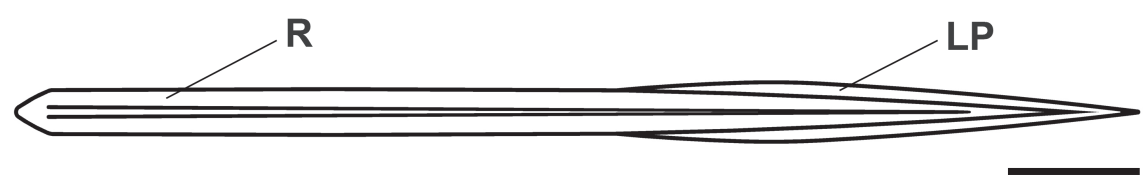

Fig. 4. Diagram of the gladius of Sepiola boletzkyi sp. nov., paratype, extremity on the left). Abbreviations: $\mathrm{R}=$ rachis, $\mathrm{LP}=$ lateral plate. Scale bar $=1 \mathrm{~mm}$. 
fold; most of lateral wall, posterior part of hood and inferior part of wing transparent. Lower beak comparatively wide; rostrum with blunt tip; jaw edge profile convex, jaw angle indistinct; blunt tooth on shoulder; no notch in hood; lateral wall without fold or ridge, roughly rectangular with lower edge slightly convex, corner faintly produced; wall and wings transparent.

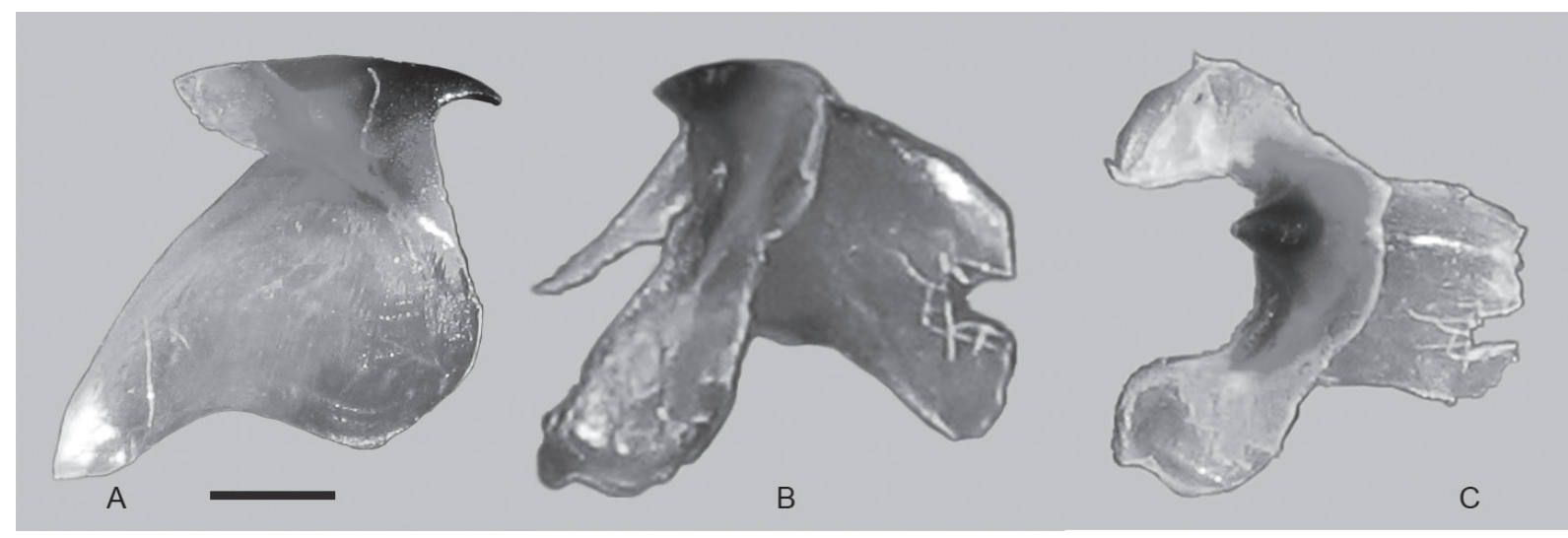

Fig. 5. Beaks of Sepiola boletzkyi sp. nov., paratype, , ESFM-CEP/1994-2. A. Upper beak, lateral view. B. Lower beak, lateral-oblique view. C. Lower beak, upper (= ventral) view. Scale bar $=1 \mathrm{~mm}$.

\section{Male}

Mature. Spermatophores $6.5 \mathrm{~mm}$ long. Mantle cavity does not show any unique traits that allows it to be distinguished from other Sepiola species. Brachial crown dimorphic. Left arm I hectocotylized (see below), arms II bear 6 pairs of enlarged suckers in middle third; arms III not evidently more robust than remaining arms and not bent inward (contrary to several Sepiola species); arms IV bear 3 pairs of enlarged suckers in middle third.

Hectocotylus (left arm I) shorter than right arm I. Basal part (refer to diagram in Fig. 1) bears three equal-sized, not markedly enlarged, suckers, two in ventral and one in dorsal row (the latter missing in holotype as result of damage) (Fig. 6A). Copulatory apparatus formed by fusion of four suckerless stalks, elongated and curved medially, projecting away from arm; ventral-most ones correspond to third and fourth stalks of ventral row; dorsal-most ones derive from second and third stalks of dorsal row, modified into roundish tubercle (Fig. 6A-B). Copulatory apparatus complemented by broad smoothpointed triangular lobe, dorsomedial to tubercle, formed from more than one dorsal suckerless stalks fused with each other (i.e., likely fourth, fifth and sixth stalks of dorsal sucker row); lobe forms groove with tubercle (Fig. 6B-C).

Distal part of hectocotylus somewhat bent, narrow (i.e., two rows of suckers not spread apart to form a spoon-like widening) (Fig. 6A). Arm tip blunt. No groove on hectocotylus lateral side facing right arm I (Fig. 6B). First two suckers of dorsal row (Fig. 6A, suckers 1-2) in distal part smaller than facing suckers of ventral row; followed by six markedly enlarged (Fig. 6A, suckers 3-8), one small (smaller than facing ventral row suckers) (Fig. 6A, sucker 9), two enlarged suckers (Fig. 6A, suckers 10-11). All enlarged suckers about the same size. Distal to enlarged suckers, remaining eight suckers gradually taper to arm tip. Sucker stalks of enlarged suckers proportionally larger and elongated. Suckers of ventral row regularly sized. 


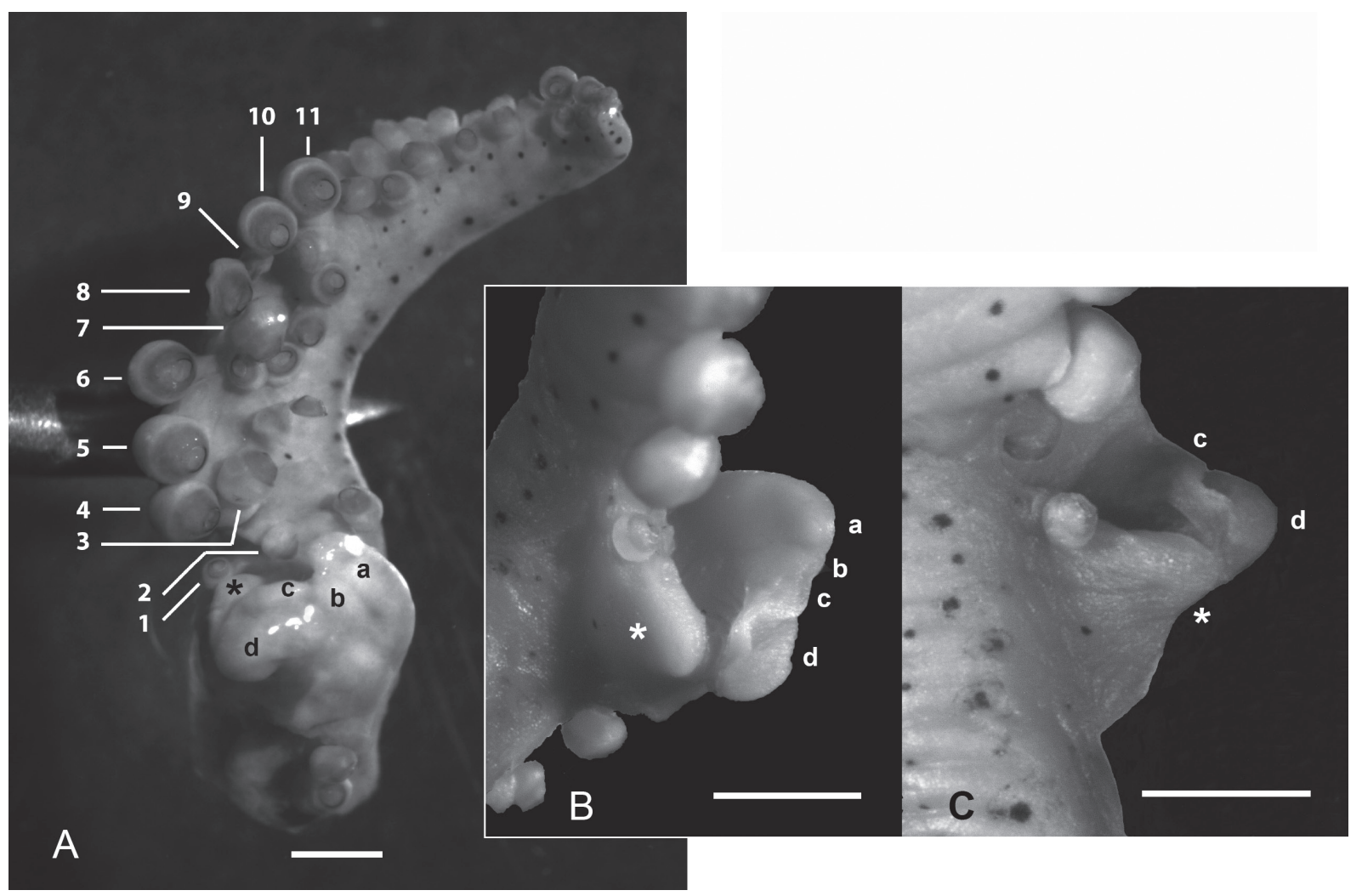

Fig. 6. Hectocotylus (left arm I) of Sepiola boletzkyi sp. nov., holotype, Ô, ESFM-CEP/1994-1. Abbreviations: $a-d=$ suckerless stalks forming the copulatory apparatus proper $(a=$ ventral-most, $d=$ dorsal-most one, i.e. tubercle); $*$ = lobe in the dorsal row of suckers, $1-11=$ sequence of heteromorphous suckers in the dorsal row of distal part. A. Oral view; the arm is slightly tilted, with the tip towards the observer, in order to show details (lobe and small suckers 1-2), otherwise hidden by the four suckerless stalks of the copulatory apparatus. Basal part: only the two ventral suckers are visible, the dorsal one is missing as a result of damage. Copulatory apparatus: the tubercle (d) partially hides the lobe in the dorsal row $(*)$. Distal part: the heteromorphous suckers in the dorsal row are 1-2 small, 3-8 enlarged, 9 small, 10-11 enlarged; the remaining suckers are regular; note that some suckers $(2,3$ and 7$)$ are displaced towards the centre of the arm, i.e., not aligned with the others of their same row; it is not known whether this is natural or caused by preservation. B. Inner-lateral view of copulatory apparatus; the lobe $(*)$ forms a groove with the tubercle (d). C. Oblique inner-lateral view of copulatory apparatus; two barely visible longitudinal lines on the lobe $(*)$ are likely fusion lines between adjacent stalks forming it. Scale bars $=1 \mathrm{~mm}$.

\section{Female}

Immature. Bursa copulatrix large, roughly ear-shaped, longer than wide; anteriorly extends below left light-organ lens, posteriorly reaches posterior end of mantle cavity (most probably this is not so in mature females with enlarged ovary), medially reaches sagittal mantle cavity septum (Fig. 7A). Folds converge towards centre of bursa where they deepen into a longitudinal opening. Posterior half of bursa bordered by elevated rim; contour elliptical, slightly pointed (like a barge prow). Large fungiform process, towards mantle wall rear of gill insertion, sticking out of bursa laterally from converging folds; stalk of process longitudinally folded; distal end larger than stalk, flat, roughly triangular with rounded corners, might be fused with mantle wall (slight possible scar on it) (Fig. 7B). 

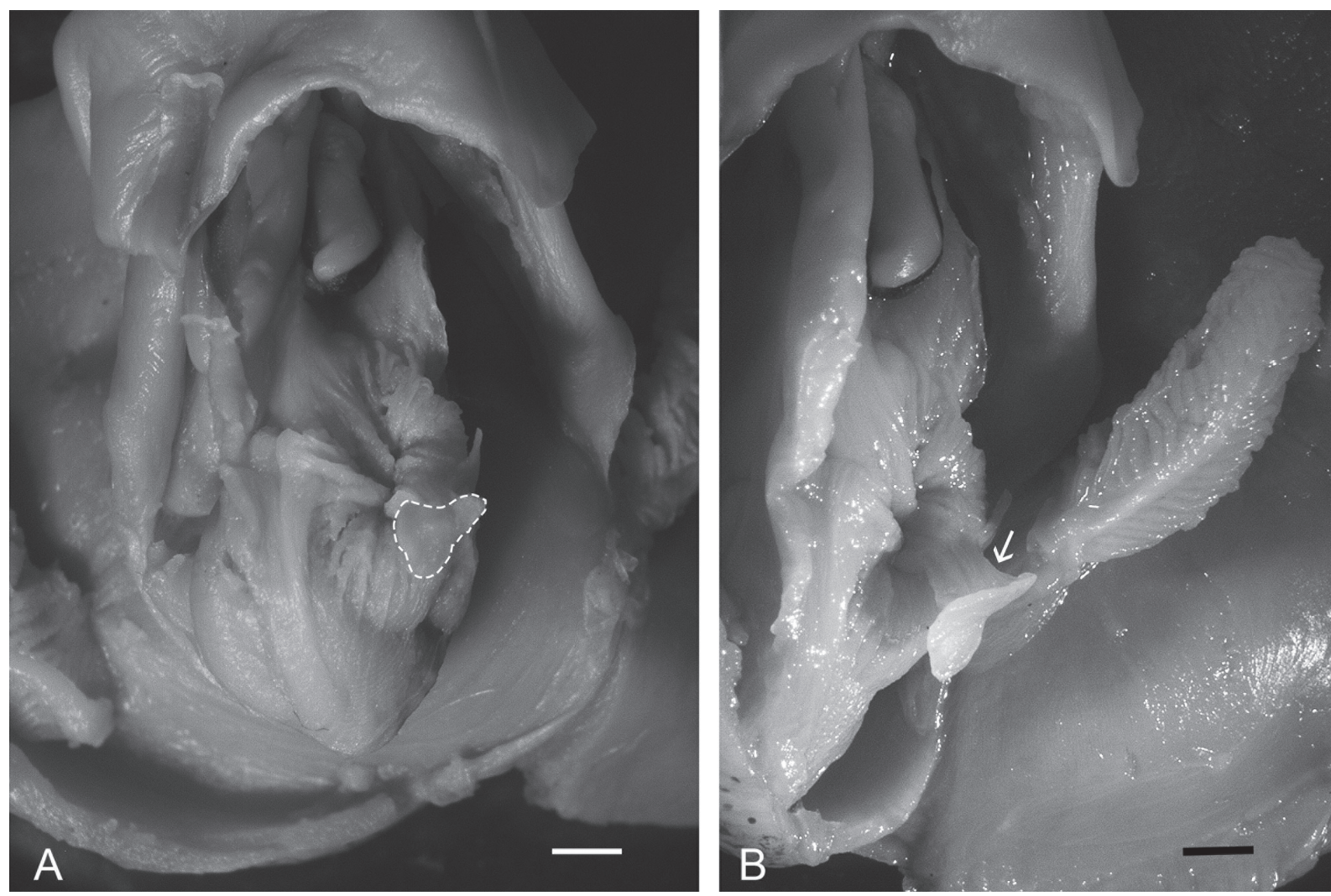

Fig. 7. Bursa copulatrix of Sepiola boletzkyi sp. nov., paratype,, , ESFM-CEP/1994-2. A. Ventral view; the dashed line encloses the distal surface of the large fungiform process. B. Oblique ventral view; the fungiform process sticks out of the bursa, laterally to the folds convergence; an arrow points to the longitudinally folded stalk of the process. Scale bar for both figures $=1 \mathrm{~mm}$.

\section{Remarks}

Sepiola boletzkyi sp. nov. can be distinguished from other species in the genus based on the hectocotylus and the bursa copulatrix. As discovered by Naef (1912a, b, 1923) these copulatory organs are speciesspecific, hence they discriminate the Sepiola species from each other (see also Bello 1995, 2013). In particular S. boletzkyi sp. nov. belongs to the Sepiola atlantica group as defined by Naef (1923), characterized by the peculiar morphology of the male copulatory apparatus (Fig. 1).

The male $S$. boletzkyi sp. nov. differs from all other species in the $S$. atlantica group because it is unique in exhibiting simultaneously the characters (1) homomorphous tip of ventral arms and (2) enlarged suckers of the dorsal row of the hectocotylus distal part that are subdivided into two groups. Character 1 is shared by $S$. affinis, $S$. bursadhaesa, $S$. intermedia, $S$. robusta and $S$. rondeletii as opposed to $S$. atlantica, S. steenstrupiana and S. tridens; character 2 is displayed only by S. atlantica and S. tridens as opposed to all other species.

It is not clear to which Sepiola species S. boletzkyi sp. nov. is closer because this new sepioline differs from all four subgroups delineated by Bello (2013) within the atlantica group. Although it shares with S. atlantica $+S$. tridens the presence of several enlarged suckers of the dorsal row of the hectocotylus distal part (character 2), it neatly differs from them because of the homomorphous tip of ventral arms (character 1). Moreover the grouping of the enlarged suckers in S. boletzkyi sp. nov. diverges from that of the other two species for the number of suckers in both the proximal and midway groups as well as, 
Table 3. Sequence, from proximal to distal, of sucker-sizes in the dorsal row of the part of the hectocotylus distal to copulatory apparatus in Sepiola atlantica (after Guerra 1986), Sepiola tridens (after de Heij \& Goud 2010) and Sepiola boletzkyi sp. nov. Peculiarities of each species are highlighted in bold; the enlarged suckers are followed by regularly tapering ones to the arm tip (Guerra 1986: fig. 3; de Heij \& Goud 2010: fig. 5; present work: Fig. 6A).

\begin{tabular}{|lc|}
\hline Sepiola atlantica & $3-4$ enlarged, 1-5 small, 3-4 enlarged \\
Sepiola tridens & $3-4$ enlarged, $2-3$ small, 5-8 enlarged \\
Sepiola boletzkyi sp. nov. & 2 small, 6 enlarged, 1 small, 2 enlarged \\
\hline
\end{tabular}

distinctively, because the first two suckers of the dorsal row are markedly small. Table 3 reports the sequence of enlarged suckers in the three species with two groups of sucker-sizes.

With respect to $(S$. affinis $+S$. bursadhaesa $+S$. intermedia $)$, which have just one group of enlarged suckers in the dorsal row of the distal part of the hectocotylus, $S$. boletzkyi sp. nov. lacks the groove on the medial side of the same distal part.

Sepiola boletzkyi sp. nov. is easily distinguished from S. rondeletii and S. robusta based on the fact they bear no enlarged suckers on the distal part of the hectocotylus and have 8 rows of suckers on the tentacle club, i.e., 2 more than in $S$. boletzkyi sp. nov. Lastly $S$. boletzkyi sp. nov. differs mostly from S. steenstrupiana because of the homomorphous tips of the ventral arms, the structure of the copulatory apparatus, the presence of enlarged suckers on the distal part of the hectocotylus, and the occurrence of 6 rows of suckers instead of $4-5$ on the tentacle club.

In addition to the abovementioned differences, the hectocotylus of $S$. boletzkyi sp. nov. is the only one among the members of the $S$. atlantica group to have a quite large lobe in the dorsal sucker row next to the copulatory apparatus tubercle.

The female S. boletzkyi sp. nov. may be discriminated from all other Sepiola species of the S. atlantica group by its unique bursa copulatrix. It differs from all members of this group, except $S$. affinis and $S$. rondeletii, because of the process projecting towards the mantle wall near the gill insertion; the process in S. boletzkyi sp. nov., however, is fungiform and larger than in both other species. Furthermore the bursa copulatrix of $S$. boletzkyi sp. nov. extends more, both anteriorly and posteriorly, than that of S. affinis and, in comparison with S. rondeletii, has no caecum (cf. Naef 1923: figs 364 and 368).

The male and female specimens herein described as holotype and paratype, respectively, of S. boletzkyi sp. nov. were assigned to the same specific entity thanks to the similarity with each other in characters other than sexual, primarily the tentacle club, in addition to having been collected in the same place.

In the only available female (the paratype), an immature specimen, the bursa copulatrix reaches the posterior end of the mantle cavity but probably it does not do so in the sexually mature female whose ovary enlarges as oocytes mature.

\section{Discussion}

Sepiola boletzkyi sp. nov. is the ninth species of the genus to be discovered in the Mediterranean Sea. It also adds to the six Sepiola species already recorded in the eastern Mediterranean Sea by Salman (2009).

As stressed in the section "Remarks", the new species is assigned, because of its hectocotylus, to the Sepiola atlantica group as defined by Naef (1923), who notably did not grant any genus-group rank to it. We adhere to Naef's concept and do not endorse any generic status for the atlantica group. The species in 
the group share, in addition to the general body bauplan, the synapomorphy of the typical hectocotylus and particularly the peculiar copulatory apparatus. According to Naef (1923: 582), in these species "the base of the hectocotylus bears 3 normal suckers, followed by a typical copulatory apparatus which develops from the stalks of 4 suckers, the 2 nd and 3 rd sucker of the median [i.e. dorsal] row and the 3 rd and 4th of the lateral [i.e. ventral] row." These four suckerless stalks are enlarged and fused together to form a typical organ followed by the distal part of the arm that may bear some enlarged suckers in the dorsal row (Figs 1, 6A). At this moment the Sepiola atlantica group includes S. affinis, S. atlantica, S. boletzkyi sp. nov., S. bursadhaesa, S. intermedia, S. robusta, S. rondeletii, S. steenstrupiana and $S$. tridens.

It is remarkable that three new Sepiola species, all belonging to the atlantica group - namely S. tridens, S. bursadhaesa and S. boletzkyi sp. nov. - have been discovered in the Atlantic-Mediterranean area in the last few years, after a century-long lapse of time since Naef (1912a, 1912b, 1916, 1923) described several new Mediterranean sepioline species and, most importantly, disentangled and re-shaped the muddled systematics of the Sepiolinae.

The genus Sepiola displays a great diversity in the Atlantic-Mediterranean area, where it is by far the most speciose cephalopod genus thanks to its 12 species. The reasons underlying this phenomenon were discussed in Bello (2013). The fairly diverse copulatory organs in males (hectocotylus) and, less conspicuously, in females (bursa copulatrix), supposedly give rise to sexual segregation and, therefore, most probably play an important role in sepioline speciation. The discovery of $S$. boletzkyi sp. nov. corroborates the hypothesis that the NE Atlantic-Mediterranean species of Sepiola are a suite of species that largely arose from in situ speciation on either side of the Strait of Gibraltar after the vicariant event(s) of (recurring) connection to the Atlantic and isolation of the Mediterranean (Bello 2013).

Sepiola boletzkyi sp. nov. is seemingly endemic to the eastern Mediterranean. Its discovery reinforces the statement by Mangold \& Boletzky (1988: 326) that "It is interesting that the only cephalopod species exclusively known from the Mediterranean are among the Sepiolinae". Indeed, as shown by Bello (2013), all or almost all Mediterranean species in the genus Sepiola are endemic or quasi-endemic; on the other side of the Strait, the NE Atlantic Sepiola species are also endemic to that area.

The description of Sepiola boletzkyi sp. nov. is based on two specimens only, a male and a female. The collection of additional specimens is necessary to define both the variability of the markedly enlarged suckers in the dorsal row of the hectocotylus distal part, in males, and the shape of the bursa copulatrix in mated females. Moreover, new supplementary material would allow tissue sampling for genetic analyses and DNA barcoding.

\section{Acknowledgements}

We thank Bahadır Önsoy (S1tkı Koçman University, Turkey) for producing the illustration of the tentacle club and for improving the beak photographs, and Aldo Corriero and Rosa Zupa (Department of Emergency and Organ Transplant, University of Bari, Italy) for their hospitality and assistance to the first author with the stereo microscope photographs. We are most grateful to Chung-Cheng Lu (Museum of Victoria, Melbourne, Australia and National Chung Hsing University, Taichung, Taiwan) for critically reading and thoroughly reviewing our paper. We also acknowledge our debt to an anonymous reviewer for her/his constructive suggestions.

\section{References}

Açik S. \& Salman A. 2010. Estimation of body size from the beaks of eight sepiolid species (Cephalopoda: Sepiolidae) from the Eastern Mediterranean Sea. Molluscan Research 30: 154-164. 
Bello G. 1995. A key for the identification of the Mediterranean sepiolids. Bulletin de l'Institut

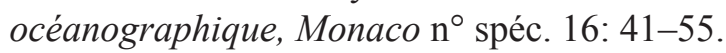

Bello G. 2003. The biogeography of Mediterranean cephalopods. Biogeographia 24: 209-226.

Bello G. 2013. Description of a new sepioline species, Sepiola bursadhaesa n. sp. (Cephalopoda: Sepiolidae), from the Catalan Sea, with remarks and identification key for the Sepiola atlantica group. Scientia Marina 77: 489-499. http://dx.doi.org/10.3989/scimar.03720.31A

Bizikov V.A. 2008. Evolution of the shell in Cephalopoda. VNIRO Publishing, Moscow.

Clarke M.R. 1986. A handbook for the identification of cephalopod beaks. Clarendon Press, Oxford.

Guerra A. 1986. Sepiolinae (Mollusca, Cephalopoda) de la Ría de Vigo. Iberus 6: 175-184.

Heij A. de \& Goud J. 2010. Sepiola tridens spec. nov., an overlooked species (Cephalopoda: Sepiolidae) living in the North Sea and north-eastern Atlantic Ocean. Basteria 74: 51-62.

Jatta G. 1896. I Cefalopodi viventi nel Golfo di Napoli. (Sistematica). Fauna und Flora des Golfes von Neapel 23, R. Friedländer \& Sohn, Berlin. http://dx.doi.org/10.5962/bhl.title.51597

Mangold K. \& Boletzky S.v. 1988. Mediterranean Cephalopod Fauna. In: Clarke M.R. \& Trueman E.R. (eds) The Mollusca. Vol. 12: Paleontology and Neontology of Cephalopods: 315-330. Academic Press, London and New York.

Naef A. 1912a. Teuthologische Notizen. 3. Die Arten der Gattungen Sepiola und Sepietta. Zoologischer Anzeiger 39: 262-271.

Naef A. 1912b. Teuthologische Notizen. 7. Zur Morphologie und Systematik der Sepiola- und SepiettaArten. Zoologischer Anzeiger 40: 78-85.

Naef A. 1916. Ueber Neue Sepioliden aus dem Golf von Neapel. Pubblicazioni della Stazione Zoologica di Napoli 1: 1-10.

Naef A. 1923. Die Cephalopoden. Fauna und Flora des Golfes von Neapel 35 (1), R. Friedländer \& Sohn, Berlin. [English translation by A. Mercado, 1972; Smithsonian Institution, Washington D.C.]

Reid A. 2009. Sepioloidea magna sp. nov.: a new bottletail squid (Cephalopoda: Sepiadariidae) from northern Australia. The Beagle, Records of the Museums and Art Galleries of the Northern Territory 25: 103-109. [available from http://ro.uow.edu.au/scipapers/296]

Roper C.F.E. \& Voss G.L. 1983. Guidelines for taxonomic descriptions of cephalopod species. Memoirs of the National Museum of Victoria 44: 48-63.

Salman A. 2009. Cephalopod research in the eastern Mediterranean (East of $23^{\circ}$ E): a review. Bollettino Malacologico 45 (suppl.): 47-59.

Manuscript received: 4 May 2015

Manuscript accepted: 12 August 2015

Published on: 12 October 2015

Topic editor: Rudy Jocqué

Desk editor: Kristiaan Hoedemakers

Printed versions of all papers are also deposited in the libraries of the institutes that are members of the EJT consortium: Muséum National d'Histoire Naturelle, Paris, France; Botanic Garden Meise, Belgium; Royal Museum for Central Africa, Tervuren, Belgium; Natural History Museum, London, United Kingdom; Royal Belgian Institute of Natural Sciences, Brussels, Belgium; Natural History Museum of Denmark, Copenhagen, Denmark. 